\title{
Detecting small-scale spatial heterogeneity and temporal dynamics of soil organic carbon (SOC) stocks: a comparison between automatic chamber-derived $\mathrm{C}$ budgets and repeated soil inventories
}

\author{
Mathias Hoffmann $^{1}$, Nicole Jurisch ${ }^{2}$, Juana Garcia Alba ${ }^{1}$, Elisa Albiac Borraz ${ }^{1}$, Marten Schmidt ${ }^{2}$, Vytas Huth ${ }^{2}$, \\ Helmut Rogasik ${ }^{1}$, Helene Rieckh ${ }^{1}$, Gernot Verch ${ }^{3}$, Michael Sommer ${ }^{1,4}$, and Jürgen Augustin ${ }^{2}$ \\ ${ }^{1}$ Institute of Soil Landscape Research, Leibniz Centre for Agricultural Landscape Research (ZALF), Eberswalder Str. 84, \\ 15374 Müncheberg, Germany \\ ${ }^{2}$ Institute of Landscape Biogeochemistry, Leibniz Centre for Agricultural Landscape Research (ZALF), Eberswalder Str. 84, \\ 15374 Müncheberg, Germany \\ ${ }^{3}$ Research Station Dedelow, Leibniz Centre for Agricultural Landscape Research (ZALF), Eberswalder Str. 84,15374 \\ Müncheberg, Germany \\ ${ }^{4}$ Institute of Earth and Environmental Sciences, University Potsdam, Karl-Liebknecht-Str. 24-25, 14476 Potsdam, Germany
}

Correspondence to: Mathias Hoffmann (mathias.hoffmann@ zalf.de)

Received: 10 August 2016 - Discussion started: 31 August 2016

Revised: 3 February 2017 - Accepted: 3 February 2017 - Published: 3 March 2017

\begin{abstract}
Carbon (C) sequestration in soils plays a key role in the global $\mathrm{C}$ cycle. It is therefore crucial to adequately monitor dynamics in soil organic carbon $(\triangle \mathrm{SOC})$ stocks when aiming to reveal underlying processes and potential drivers. However, small-scale spatial (10-30 m) and temporal changes in SOC stocks, particularly pronounced in arable lands, are hard to assess. The main reasons for this are limitations of the well-established methods. On the one hand, repeated soil inventories, often used in long-term field trials, reveal spatial patterns and trends in $\triangle \mathrm{SOC}$ but require a longer observation period and a sufficient number of repetitions. On the other hand, eddy covariance measurements of $\mathrm{C}$ fluxes towards a complete $\mathrm{C}$ budget of the soil-plant-atmosphere system may help to obtain temporal $\triangle \mathrm{SOC}$ patterns but lack small-scale spatial resolution.

To overcome these limitations, this study presents a reliable method to detect both short-term temporal dynamics as well as small-scale spatial differences of $\triangle$ SOC using measurements of the net ecosystem carbon balance (NECB) as a proxy. To estimate the NECB, a combination of automatic chamber (AC) measurements of $\mathrm{CO}_{2}$ exchange and empirically modeled aboveground biomass development $\left(\mathrm{NPP}_{\text {shoot }}\right)$ were used. To verify our method, results were compared with $\Delta$ SOC observed by soil resampling.
\end{abstract}

Soil resampling and AC measurements were performed from 2010 to 2014 at a colluvial depression located in the hummocky ground moraine landscape of northeastern Germany. The measurement site is characterized by a variable groundwater level (GWL) and pronounced small-scale spatial heterogeneity regarding SOC and nitrogen $(\mathrm{Nt})$ stocks. Tendencies and magnitude of $\triangle$ SOC values derived by AC measurements and repeated soil inventories corresponded well. The period of maximum plant growth was identified as being most important for the development of spatial differences in annual $\Delta S O C$. Hence, we were able to confirm that AC-based $\mathrm{C}$ budgets are able to reveal small-scale spatial differences and short-term temporal dynamics of $\triangle \mathrm{SOC}$.

\section{Introduction}

Soils are the largest terrestrial reservoirs of soil organic carbon (SOC), storing 2 to 3 times as much $\mathrm{C}$ as the atmosphere and biosphere (Chen et al., 2015; Lal et al., 2004). In the context of climate change mitigation as well as soil fertility and food security, there has been considerable interest in the development of SOC, especially in erosion-affected agricultural landscapes (Berhe and Kleber, 2013; Conant et 
al., 2011; Doetterl et al., 2016; Stockmann et al., 2015; Van Oost et al., 2007; Xiong et al., 2016). Detecting the development of soil organic carbon stocks $(\triangle \mathrm{SOC})$ in agricultural landscapes needs to consider three major challenges: first, the high small-scale spatial heterogeneity of SOC (e.g., Conant et al., 2011; Xiong et al., 2016). Erosion and land use change reinforce natural spatial and temporal variability, especially in hilly landscapes such as hummocky ground moraines where correlation lengths in soil parameters of 10$30 \mathrm{~m}$ are very common. Second, pronounced short-term temporal dynamics, caused by, e.g., type of cover crop, frequent crop rotation and soil cultivation practices need to be considered. Third, the rather small magnitude of $\triangle \mathrm{SOC}$ compared to total SOC stocks need to be considered (e.g., Conant et al., 2011; Poeplau et al., 2016).

However, information on the development of SOC is an essential precondition to improve the predictive ability of terrestrial C models (Luo et al., 2016). As a result, sensitive measurement techniques are required to precisely assess short-term temporal and small-scale $(10-30 \mathrm{~m})$ spatial dynamics in $\triangle$ SOC (Batjes and van Wesemael, 2015). To date, the assessment of $\triangle \mathrm{SOC}$ has typically been based on two methods, namely (i) destructive, repeated soil inventories through soil resampling and (ii) non-destructive determination of net ecosystem $\mathrm{C}$ balance (NCEB) by measurements of gaseous $\mathrm{C}$ exchange, $\mathrm{C}$ import and $\mathrm{C}$ export (Leifeld et al., 2011; Smith et al., 2010).

The first method is usually used during long-term field trials (Batjes and van Wesemael, 2015; Chen et al., 2015; Schrumpf et al., 2011). Given a sufficient time horizon of 5 to 10 years, the soil resampling method is generally able to reveal spatial patterns and trends within $\triangle \mathrm{SOC}$ (Batjes and van Wesemael, 2015; Schrumpf et al., 2011). Most repeated soil inventories are designed to study treatment differences in the long term. As a result, short-term temporal dynamics in C exchange remain concealed (Poeplau et al., 2016; Schrumpf et al., 2011). A number of studies tried to overcome this methodical limitation by increasing (e.g., to monthly) the soil sampling frequency (Culman et al., 2013; Wuest, 2014). This allows for the detection of seasonal patterns of $\triangle \mathrm{SOC}$ but still mixes temporal and spatial variability of SOC because every new soil sample represents not only a repetition in time but also in space. Temporal differences observed through repeated soil sampling are therefore always spatially biased.

By contrast, the NECB (Smith et al., 2010) - used as a proxy for temporal dynamics of $\triangle \mathrm{SOC}$ - can be easily derived through the eddy covariance (EC) technique, representing a common approach to obtaining gaseous $\mathrm{C}$ exchange (Alberti et al., 2010; Leifeld et al., 2011; Skinner and Dell, 2015). However, C fluxes based on EC measurements are integrated over a larger, changing footprint area (several hectares). As a result, small-scale $(<20 \mathrm{~m})$ spatial differences in NECB and $\triangle \mathrm{SOC}$ are not detected.

Accounting for the abovementioned methodical limitations, a number of studies investigated spatial patterns in gaseous $\mathrm{C}$ exchange by using manual chamber measurement systems (Eickenscheidt et al., 2014; Pohl et al., 2015). Compared to EC measurements, these systems are characterized by a low temporal resolution, where the calculated net ecosystem $\mathrm{CO}_{2}$ exchange (NEE) is commonly based on extensive gap filling (Gomez-Casanovas et al., 2013; Savage and Davidson, 2003) conducted using empirical modeling, for example (Hoffmann et al., 2015). Therefore, management practices and different stages in plant development that are needed to precisely detect NEE often remain unconsidered (Hoffmann et al., 2015).

Compared to previously mentioned approaches for detecting $\triangle \mathrm{SOC}$ by either repeated soil sampling or observations of the gaseous $\mathrm{C}$ exchange, automatic chamber (AC) systems combine several advantages. On the one hand, flux measurements of the same spatial entity avoid the mixing of spatial and temporal variability, as done in the case of point measurements from repeated soil inventories. On the other hand, AC measurements combine the advantages of EC and manual chamber systems because they not only increase the temporal resolution compared to manual chambers but also allow for the detection of small-scale spatial differences and treatment comparisons regarding the gaseous $\mathrm{C}$ exchange (Koskinen et al., 2014).

To date, hardly any direct comparisons between ACderived $\mathrm{C}$ budgets and soil resampling-based $\triangle \mathrm{SOC}$ values have been reported in the literature. Leifeld et al. (2011) and Verma et al. (2005) compared the results of repeated soil inventories with EC-based C budgets over 5- and 3year study periods, respectively. Even though temporal dynamics in $\triangle \mathrm{SOC}$ were shown for grazed pastures and intensively used grasslands, for example (Skinner and Dell, 2015; Leifeld et al., 2011), no attempt was made to additionally detect small-scale differences in $\triangle$ SOC. In our study, we introduce the combination of $\mathrm{AC}$ measurements and empirically modeled aboveground biomass production $\left(\mathrm{NPP}_{\text {shoot }}\right)$ as a precise method to detect small-scale spatial differences and short-term temporal dynamics of NECB and thus $\triangle$ SOC. Measurements were performed from 2010 to 2014 under a silage maize - winter fodder rye - sorghum-Sudan grass hybrid - alfalfa crop rotation at an experimental plot located in the hummocky ground moraine landscape of northeastern Germany.

We hypothesize that the AC-based $\mathrm{C}$ budget method is able to detect small-scale spatial and short-term temporal dynamics of NECB and thus $\triangle \mathrm{SOC}$ in an accurate and precise manner. Therefore, we compare $\triangle \mathrm{SOC}$ values measured by soil resampling with NECB values derived through AC-based C budgets (Fig. 1). 


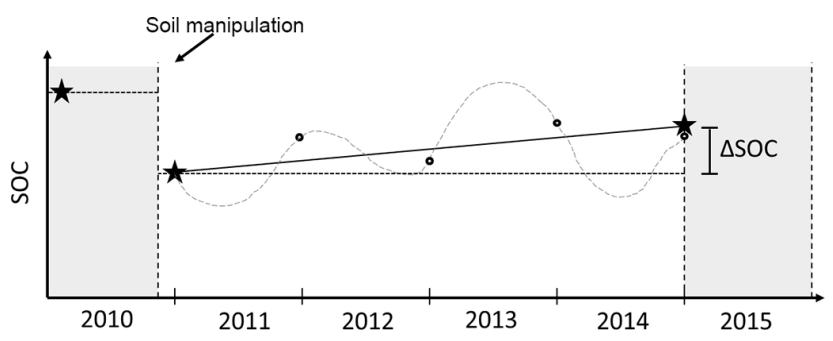

Figure 1. Schematic representation of the study concept used to detect changes in soil organic carbon stock $(\Delta \mathrm{SOC})$. Black stars represent SOC measured by the soil resampling method. Black circles represent annual NECB derived using the $\mathrm{C}$ budget method.

\section{Materials and methods}

\subsection{Study site and experimental setup}

Measurements were performed at the 6 ha experimental field "CarboZALF-D". The site is located in a hummocky arable soil landscape within the Uckermark region (northeastern Germany, $53^{\circ} 23^{\prime} \mathrm{N}, 13^{\circ} 47^{\prime} \mathrm{E}, \sim 50-60 \mathrm{~m}$ a.s.l.). The temperate climate is characterized by a mean annual air temperature of $8.6^{\circ} \mathrm{C}$ and annual precipitation of $485 \mathrm{~mm}(1992-$ 2012, ZALF research station, Dedelow). Typical landscape elements vary from flat summit and depression locations with a gradient of approximately $2 \%$, across longer slopes with a medium gradient of approximately $6 \%$, to short and rather steep slopes with a gradient of up to $13 \%$. The study site shows complex soil patterns mainly influenced by erosion and relief and parent material, e.g., sandy to marly glacial and glaciofluvial deposits. The soil-type inventory of the experimental site consists of non-eroded Albic Luvisols (Cutanic) at the flat summits, strongly eroded Calcic Luvisols (Cutanic) on the moderate slopes, extremely eroded Calcaric Regosols (Densic) on the steep slopes and a colluvial soil, i.e., Endogleyic Colluvic Regosols (Eutric), over peat in the depression (IUSS Working Group WRB, 2015).

During June 2010, four automatic chambers and a WXT520 climate station (Vaisala, Vantaa, Finland) were set up at the depression (Sommer et al., 2016) (see Sect. 2.2.1). The chambers were arranged along a topographic gradient (upper (A), upper middle (B), lower middle (C) and lower (D) chamber position; length $\sim 30 \mathrm{~m}$; difference in altitude $\sim 1 \mathrm{~m}$ ) within a distance of approximately $5 \mathrm{~m}$ of each other (Fig. 2). As part of the CarboZALF project, a manipulation experiment was carried out at the end of October 2010, i.e., after the vegetation period (Deumlich et al., 2017). Topsoil material from a neighboring hillslope was incorporated into the upper soil layer of the depression (Ap horizon). The amount of translocated soil was equivalent to tillage erosion of a decennial time horizon (Sommer et al., 2016). The change in SOC for each chamber was monitored by three topsoil inventories, carried out (I) prior to soil manipulation during April 2009, (II) after soil manipulation during April 2011

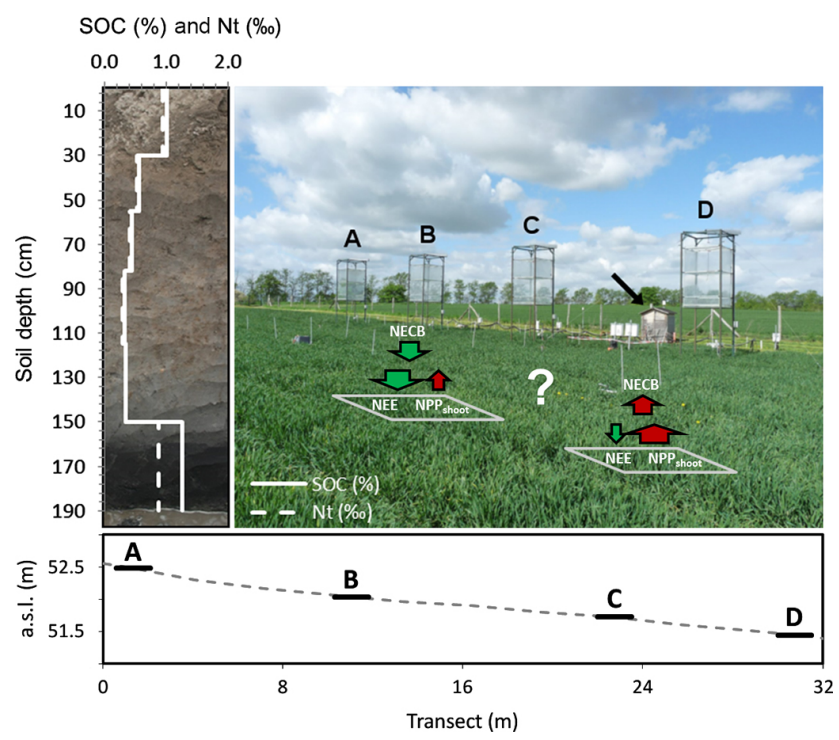

Figure 2. Transect of automatic chambers and chamber positions within the depression overlying the Endogleyic Colluvic Regosol (WRB 2015, left). The black arrow shows the position of the data logger and controlling devices, which were placed within a wooden, weather-sheltered house. The soil profile is shown on the left. Soil horizon-specific SOC (\%) and Nt (\%) contents are indicated by solid and dashed vertical white lines, respectively. Spatial differences in NECB and the basic principle of the C budget method are shown as the scheme within the picture.

and (III) during December 2014. $\triangle$ SOC derived through soil resampling and $\mathrm{AC}$-based $\mathrm{C}$ budgets (to determine NECB) was compared for the period between April 2011 and December 2014 (Fig. 1).

Records of meteorological conditions (1 min frequency) include measurements of air temperature at 20 and $200 \mathrm{~cm}$ height, PAR (photosynthetic active radiation; inside and outside the chamber), air humidity, precipitation, air pressure, wind speed and direction. Soil temperatures at depths of 2, 5, 10 and $50 \mathrm{~cm}$ were recorded using thermocouples installed next to the climate station (107, Campbell Scientific, UT, USA).

The groundwater level (GWL) was measured using tensiometers assuming hydrostatic equilibrium. The tensiometers were installed at a soil depth of $160 \mathrm{~cm}$ at soil profile locations near chamber B and between chambers C and D. The average GWL of both profiles was used for further data analysis. Data gaps $<2$ days were filled using simple linear interpolation. Larger gaps in GWL did not occur. The measurement site was cultivated with five different crops during the study period, following a practice-orientated and erosion-expedited farming procedure. The crop rotation was silage maize (Zea mays) - winter fodder rye (Secale cereale) - sorghum-Sudan grass hybrid (Sorghum bicolor $x$ sudanese) - winter triticale (Triticosecale) - alfalfa (Medicago sativa). Cultivation and fertilization details are presented in 
Table A1. Aboveground biomass ( $\mathrm{NPP}_{\text {shoot }}$ ) development was monitored using up to four biomass sampling campaigns during the growing season, covering the main growth stages. Additional measurements of leaf area index (LAI) started in 2013. Collected biomass samples were chopped and dried to a constant weight $\left(48 \mathrm{~h}\right.$ at $\left.105^{\circ} \mathrm{C}\right)$. The $\mathrm{C}, \mathrm{N}, \mathrm{K}$ and $\mathrm{P}$ contents were determined using elementary analysis $(\mathrm{C}$, N; TruSpec CNS analyzer, LECO Ltd., Mönchengladbach, Germany) and Kjehldahl digestion (P, K; AT200, Beckman Coulter (Olympus), Krefeld, Germany and AAS-iCE3300, Thermo Fisher Scientific GmbH, Darmstadt, Germany). To assess the potential impact of chamber placement on plant growth, chemical analyses were carried out for the final harvests of each chamber and were compared to biomass samples collected next to each chamber.

\subsection{C budget method}

\subsubsection{Automatic chamber system}

Automatic flow-through non-steady-state (FT-NSS) chamber measurements (Livingston and Hutchinson, 1995) of $\mathrm{CO}_{2}$ exchange were conducted from January 2010 until December 2014. The AC system consists of four identical, rectangular, transparent polycarbonate chambers (thickness of $2 \mathrm{~mm}$, light transmission $\sim 70 \%$ ). Each chamber has a height of $2.5 \mathrm{~m}$ and covers a surface area of $2.25 \mathrm{~m}^{2}$ (volume: $5.625 \mathrm{~m}^{3}$ ). To adapt for plant height (alfalfa), the chamber volume was reduced to $3.375 \mathrm{~m}^{3}$ in autumn 2013. Airtight closure during measurements was ensured by a rubber belt that sealed at the bottom of each chamber. A $30 \mathrm{~cm}$ openended tube on the slightly concave top of the chambers guided rain water into the chamber and additionally assured pressure equalization. Two small axial fans $\left(5.61 \mathrm{~m}^{3} \mathrm{~min}^{-1}\right)$ were used for mixing the chamber headspace. The chambers were mounted onto steel frames with a height of $6 \mathrm{~m}$ and lifted between measurements using electrical winches at the top. For controlling the AC system and data collection, a CR1000 data logger was used (Campbell Scientific, UT, USA). The $\mathrm{CO}_{2}$ concentration changes over time were measured within each chamber using a carbon dioxide probe (GMP343, Vaisala, Vantaa, Finland) connected to a vacuum pump $\left(0.001 \mathrm{~m}^{3} \mathrm{~min}^{-1}\right.$; DC12/16FK, Fürgut, Tannheim, Germany). All $\mathrm{CO}_{2}$ probes were calibrated prior to installation using $\pm 0.5 \%$ accurate gases containing 0,200 , $370,600,1000$ and $4000 \mathrm{ppm} \mathrm{CO}_{2}$. The operation schedule of the AC system, decisively influenced by agricultural treatments, is presented in Table A1. The chambers closed in parallel at an hourly frequency, providing one flux measurement per chamber and hour. The measurement duration was 5-20 min, depending on season and time of day. Nighttime measurements usually lasted $10 \mathrm{~min}$ during the growing season and 20 min during the non-growing season (due to lower concentration increments). The length of the daytime measurements was up to $10 \mathrm{~min}$, depending on low PAR fluctua- tions $(<20 \%) . \mathrm{CO}_{2}$ concentrations (inside the chamber) and general environmental conditions, such as PAR (SKP215, Skye, Llandrindod Wells, UK) and air temperatures (107, Campbell Scientific, UT, USA), were recorded inside and outside the chambers at a 1 min frequency from 2010 to 2012 and a $15 \mathrm{~s}$ frequency from October 2012.

\subsection{2 $\mathrm{CO}_{2}$ flux calculation and gap filling}

An adaptation of the modular $\mathrm{R}$ program script, described in detail by Hoffmann et al. (2015), was used for stepwise data processing. The atmospheric sign convention was used for the components of gaseous $\mathrm{C}$ exchange (ecosystem respiration ( $R_{\mathrm{eco}}$; sum of autotrophic and heterotrophic respiration), gross primary production (GPP) and NEE), whereas positive values for NECB indicate a gain and negative values a loss in SOC. Based on records of environmental variables and $\mathrm{CO}_{2}$ concentration change within the chamber headspace, $\mathrm{CO}_{2}$ fluxes were calculated and parameterized for $R_{\text {eco }}$ and GPP within an integrative step. Subsequently, $R_{\mathrm{eco}}$, GPP and NEE were modeled for the entire measurement period using climate station data. Statistical analyses, model calibration and comprehensive error prediction were provided for all steps of the modeling process.

$\mathrm{CO}_{2}$ fluxes $\left(F, \mu \mathrm{mol} \mathrm{C} \mathrm{m}{ }^{-2} \mathrm{~s}^{-1}\right)$ were calculated according to the ideal gas law (Eq. 1).

$$
F=\frac{p V}{R T A} \cdot \frac{\Delta c}{\Delta t},
$$

where $\Delta c / \Delta t$ is the concentration change over measurement time, $A$ and $V$ denote the basal area and chamber volume, respectively, and $T$ and $p$ represent the air temperature inside the chamber $(\mathrm{K})$ and air pressure. Because plants below the chambers accounted for $<0.2 \%$ of the total chamber volume, a static chamber volume was assumed. $R$ is a constant $\left(8.3143 \mathrm{~m}^{3} \mathrm{~Pa} \mathrm{~K}^{-1} \mathrm{~mol}^{-1}\right)$. To calculate $\Delta c / \Delta t$, data subsets based on a variable moving window with a minimum length of 4 min were used (Hoffmann et al., 2015). $\Delta c / \Delta t$ was computed by applying a linear regression to each data subset, relating changes in chamber headspace $\mathrm{CO}_{2}$ concentration to measurement time (Leiber-Sauheitl et al., 2013; Leifeld et al., 2014; Pohl et al., 2015). In the case of the $15 \mathrm{~s}$ measurement frequency, a death band of $5 \%$ was applied prior to the moving window algorithm. Thus, data noise that originated from either turbulence or pressure fluctuation caused by chamber deployment or from increasing saturation and canopy microclimate effects was excluded (Davidson et al., 2002; Kutzbach et al., 2007; Langensiepen et al., 2012). Due to the low measurement frequency, no data points were discarded for records with 1 min measurement frequency (2010-2012). The resulting $\mathrm{CO}_{2}$ fluxes per measurement (based on the moving window data subsets) were further evaluated according to the following exclusion criteria: (i) range of within-chamber air temperature not larger than $\pm 1.5 \mathrm{~K}$ ( $R_{\text {eco }}$ and NEE fluxes) and a PAR deviation 
(NEE fluxes only) not larger than $\pm 20 \%$ of the average to ensure stable environmental conditions within the chamber throughout the measurement; (ii) significant regression slope ( $p \leq 0.1, t$ test); and (iii) non-significant tests $(p>0.1)$ for normality (Lilliefors adaption of the Kolmogorov-Smirnov test), homoscedasticity (Breusch-Pagan test) and linearity of $\mathrm{CO}_{2}$ concentration data. Calculated $\mathrm{CO}_{2}$ fluxes that did not meet all exclusion criteria were discarded. In cases where more than one flux per measurement met all exclusion criteria, the $\mathrm{CO}_{2}$ flux with the steepest slope was chosen.

To account for measurement gaps and to obtain cumulative NEE values, empirical models were derived based on nighttime $R_{\text {eco }}$ and daytime NEE measurements following Hoffmann et al. (2015). For $R_{\text {eco }}$, temperature-dependent Arrhenius-type models were used and fitted for recorded air as well as soil temperatures in different depths (Lloyd and Taylor, 1994; Eq. 2).

$$
R_{\mathrm{eco}}=R_{\mathrm{ref}} \cdot e^{E_{0}\left(\frac{1}{T_{\mathrm{ref}}-T_{0}}-\frac{1}{T-T_{0}}\right)},
$$

where $R_{\text {eco }}$ is the measured ecosystem respiration rate $\left[\mu \mathrm{mol}^{-1} \mathrm{C} \mathrm{m}^{-2} \mathrm{~s}^{-1}\right], R_{\text {ref }}$ is the respiration rate at the reference temperature $\left(283.15 \mathrm{~K}, T_{\text {ref }}\right), E_{0}$ is an activation energy-like parameter, $T_{0}$ is the starting temperature constant $(227.13 \mathrm{~K})$ and $T$ is the mean air or soil temperature during the flux measurement. Out of the four $R_{\text {eco }}$ models (one model for air temperature; soil temperature at 2,5 and $10 \mathrm{~cm}$ depth) obtained for nighttime $R_{\text {eco }}$ measurements of a certain period, the model with the lowest Akaike information criterion (AIC) was used.

GPP fluxes were derived using a PAR-dependent, rectangular hyperbolic light-response function based on the Michaelis-Menten kinetic (Elsgaard et al., 2012; Hoffmann et al., 2015; Wang et al., 2013; Eq. 3). Because GPP was not measured directly, GPP fluxes were calculated as the difference between measured NEE and modeled $R_{\text {eco }}$ fluxes.

$\mathrm{GPP}=\frac{\mathrm{GP}_{\max } \cdot \alpha \cdot \mathrm{PAR}}{\alpha \cdot \mathrm{PAR}+\mathrm{GP}_{\max }}$,

where GPP is the calculated gross primary productivity $\left(\mu \mathrm{mol}^{-1} \mathrm{CO}_{2} \mathrm{~m}^{-2} \mathrm{~s}^{-1}\right), \mathrm{GP}_{\max }$ is the maximum rate of $\mathrm{C}$ fixation at infinite PAR $\left(\mu \mathrm{mol} \mathrm{CO}_{2} \mathrm{~m}^{-2} \mathrm{~s}^{-1}\right), \alpha$ is the light use efficiency ( $\mathrm{mol} \mathrm{CO}_{2} \mathrm{~mol}^{-1}$ photons) and PAR is the photon flux density (inside the chamber) of the photosynthetically active radiation $\left(\mu \mathrm{mol}^{-1}\right.$ photons $\left.\mathrm{m}^{-2} \mathrm{~s}^{-1}\right)$. In cases where the rectangular hyperbolic light-response function did not result in significant parameter estimates, a non-rectangular hyperbolic light-response function was used (Gilmanov et al., 2007, 2013; Eq. 4).

$$
\begin{aligned}
\mathrm{GPP} & =\alpha \cdot \mathrm{PAR}+\mathrm{GP}_{\max } \\
- & \sqrt{\left(\alpha \cdot \mathrm{PAR}+\mathrm{GP}_{\max }\right)^{2}-4 \cdot \alpha \cdot \mathrm{PAR} \cdot \mathrm{GP}_{\max } \cdot \theta},
\end{aligned}
$$

where $\theta$ is the convexity coefficient of the light-response equation (dimensionless).
Due to plant growth and season, parameters of derived $R_{\text {eco }}$ and GPP models may vary with time. To account for this, a moving window parameterization was performed, by applying fluxes of a variable time window (2-21 consecutive measurement days) to Eqs. (2)-(4). Temporally overlapping $R_{\text {eco }}$ and GPP model sets were evaluated and discarded in case of positive (GPP), negative $\left(R_{\text {eco }}\right)$ or insignificant parameter estimates. Finally, the model set with the lowest AIC $\left(R_{\text {eco }}\right)$ was used. If no fit or a non-significant fit was achieved, averaged flux rates were applied for $R_{\text {eco }}$ and GPP. The length of the averaging period was thereby selected by choosing the variable moving window with the lowest standard deviation (SD) of measured fluxes. This procedure was repeated until the whole study period was parameterized.

Based on continuously monitored temperature and PAR (outside the chamber), $R_{\text {eco }}$, GPP and NEE were modeled in half-hour steps for the entire study period. Because GPP was parameterized based on PAR records inside but modeled with PAR records outside the chamber, no PAR correction in terms of reduced light transmission was needed. Uncertainty of annual $\mathrm{CO}_{2}$ exchange was quantified using a comprehensive error prediction algorithm described in detail by Hoffmann et al. (2015).

\subsubsection{Modeling aboveground biomass dynamics}

Aboveground biomass development $\left(\mathrm{NPP}_{\text {shoot }}\right)$ was predicted using a logistic empirical model (Yin et al., 2003; Zeide, 1993). From 2010 to 2012, modeled NPP shoot was based on the relationship between sampling date and the $\mathrm{C}$ content of harvested dry biomass measured during sampling campaigns (three to four times per year following plant development). For alfalfa in 2013 and 2014, NPP shoot was modeled based on measurements of LAI taken once every 2 weeks because no additional biomass sampling was performed between the multiple cuts per year. To calculate the $\mathrm{C}$ content corresponding to the measured LAI, the relationship between LAI prior to the chamber harvest and the $\mathrm{C}$ content measured in the chamber harvest of all six alfalfa cuts was used. Daily values of $\mathrm{C}$ stored within $\mathrm{NPP}_{\text {shoot }}$ were calculated using derived logistic functions.

\subsubsection{Calculation of NECB}

Annual NECB for each chamber was determined as the sum of annual NEE and $\mathrm{NPP}_{\text {shoot }}$, representing $\mathrm{C}$ removal due to the chamber harvest (Eq. 4; Leifeld et al., 2014). Temporal dynamics in NECB were calculated as the sum of daily NEE and $\mathrm{NPP}_{\text {shoot }}$.

$$
\begin{aligned}
& \mathrm{NECB}_{n}=\sum_{i=1}^{n}\left[\mathrm{NEE}_{i}+\mathrm{CH}_{4}+\left(\mathrm{NPP}_{\text {shoot }_{i}}-\mathrm{C}_{\text {import }}\right)\right. \\
& \left.+\Delta \mathrm{DOC}_{i}+\Delta \mathrm{DIC}_{i}\right]
\end{aligned}
$$

Several minor components of Eq. (5) were not considered (see also Hernandez-Ramirez et al., 2011). First, C import 
$\left(\mathrm{C}_{\text {import }}\right)$ due to seeding and fertilization, which was close to zero because the measurement site was fertilized by a surface application of mineral fertilizer throughout the entire study period, was not considered. Second, methane $\left(\mathrm{CH}_{4}-\mathrm{C}\right)$ emissions, which were measured manually at the same experimental field but did not exceed a relevant order of magnitude $\left(-0.01 \mathrm{~g} \mathrm{C} \mathrm{m}^{-2} \mathrm{yr}^{-1}\right)$ were not included in the NECB calculation. Third, lateral $\mathrm{C}$ fluxes, originating from dissolved organic carbon (DOC) and dissolved inorganic carbon (DIC) as well as particulate soil organic carbon $\left(\mathrm{SOC}_{\mathrm{p}}\right)$, were not considered. In addition to the rather small magnitude of the subsurface lateral C fluxes in soil solution (Rieckh et al., 2012), it was assumed that their $C$ input equaled $C$ output at the plot scale. Lateral $\mathrm{SOC}_{\mathrm{p}}$ transport along the hillslope was excluded by grassland stripes established between experimental plots in 2010 (Fig. 1 in Sommer et al., 2016).

\subsection{Soil resampling method}

To obtain $\triangle$ SOC using the soil resampling method, soil samples were collected three times during the study period. Initial SOC along the topographic gradient was monitored prior to soil manipulation during April 2009 at two soil pits, which were sampled by pedogenetic horizons. After soil manipulation, a $5 \mathrm{~m}$ raster sampling of topsoils (Ap horizons) was performed during April 2011. Each Ap horizon was separated into an upper $(0-15 \mathrm{~cm})$ and lower segment $(15-25 \mathrm{~cm})$, which were analyzed separately for bulk density, SOC, total nitrogen $(\mathrm{Nt})$ and coarse fraction $(<2 \mathrm{~mm})$ (data not shown). From these data, SOC and Nt mass densities were calculated separately for each segment and finally summed up for the entire Ap horizon $(0-25 \mathrm{~cm})$. The mean SOC and Nt content for the Ap horizon of each raster point was calculated by dividing SOC or Nt mass densities $(0-25 \mathrm{~cm})$ through the fine-earth mass $(0-25 \mathrm{~cm})$. In December 2014, composite soil samples of the Ap horizon were collected. The composite samples consist of samples from four sampling points in a close proximity around each chamber. Prior to laboratory analysis, coarse organic material was discarded from collected soil samples (Schlichting et al., 1995). Thermogravimetric desiccation at $105^{\circ} \mathrm{C}$ was performed in the laboratory for all samples to determine bulk densities $\left(\mathrm{Mg} \mathrm{m}^{-3}\right)$. Bulk soil samples were air dried, gently crushed and sieved $(2 \mathrm{~mm})$ to obtain the fine fraction (particle size $<2 \mathrm{~mm}$ ). The total carbon and total nitrogen contents were determined by elementary analysis (TruSpec CNS analyzer, LECO Ltd., Mönchengladbach, Germany) using carbon dioxide via infrared detection after dry combustion at $1250^{\circ} \mathrm{C}$ (DIN ISO10694, 1996), in duplicate. As the soil horizons did not contain carbonates, total carbon was equal to SOC.

\subsection{Uncertainty prediction and statistical analysis}

Uncertainty prediction for NECB derived by the C budget method was performed according to Hoffmann et al. (2015), following the law of error propagation. To test for differences in topsoil $\mathrm{SOC}\left(\mathrm{SOC}_{\mathrm{Ap}}\right)$ and $\mathrm{Nt}$ stocks in soil resampling performed after soil manipulation in 2010 and 2014, a paired $t$ test was applied. Computation of uncertainty prediction and calculation of statistical analyses were performed using $\mathrm{R}$ 3.2.2.

\section{Results}

\subsection{C budget method}

\subsubsection{NEE and NPP shoot dynamics}

NEE and its components $R_{\text {eco }}$ and GPP were characterized by a clear seasonality and diurnal patterns. Seasonality followed plant growth and management events (e.g., harvest; Fig. 3). Highest $\mathrm{CO}_{2}$ uptake was thus observed during the growing season, whereas NEE fluxes during the nongrowing season were significantly lower. Diurnal patterns were more pronounced during the growing season and less obvious during the non-growing season. In general, $R_{\text {eco }}$ fluxes were higher during the daytime, whereas GPP and NEE, in the case of present cover crops, were lower or even negative, representing a $\mathrm{C}$ uptake during daytime by the plant-soil system. Annual NEE was crop dependent, ranging from -1600 to $-288 \mathrm{~g} \mathrm{C} \mathrm{m}^{-2} \mathrm{yr}^{-1}$. The highest annual uptakes were observed for maize and sorghum during 2011 and 2012, whereas alfalfa cultivation showed lower annual NEE (Table 1). From 2010 to 2012, annual NEE followed the topographic gradient, with higher NEE in the direction of the depression and lower NEE away from the depression. These small-scale spatial differences in gaseous $\mathrm{C}$ exchange changed with alfalfa cultivation. As a result, only minor differences between the chamber positions were observed, showing no clear trend or tendency (Table 1).

$\mathrm{C}$ in living biomass (due to biomass sampling campaigns and LAI measurements) and $\mathrm{C}$ removals due to harvest were in general well reflected by modeled $\mathrm{NPP}_{\text {shoot }}$ (Fig. 4). Annual $\mathrm{C}$ removal due to harvest was clearly crop dependent, with highest $\mathrm{NPP}_{\text {shoot }}$ for maize and sorghum ranging from 420 to $1238 \mathrm{~g} \mathrm{C} \mathrm{m}^{-2}$ and lower values in the case of winter fodder rye and alfalfa. Similar to NEE from 2010 to 2012, annual sums of $\mathrm{NPP}_{\text {shoot }}$ followed the topographic gradient, with lower values close to the depression (Table 1). Again, lower differences in annual $\mathrm{NPP}_{\text {shoot }}$ between the chambers and no spatial trends were found for alfalfa in 2013 and 2014.

\subsubsection{NECB dynamics}

Temporal and spatial dynamics of continuously cumulated daily NECB values during the 4 years after soil manipulation 

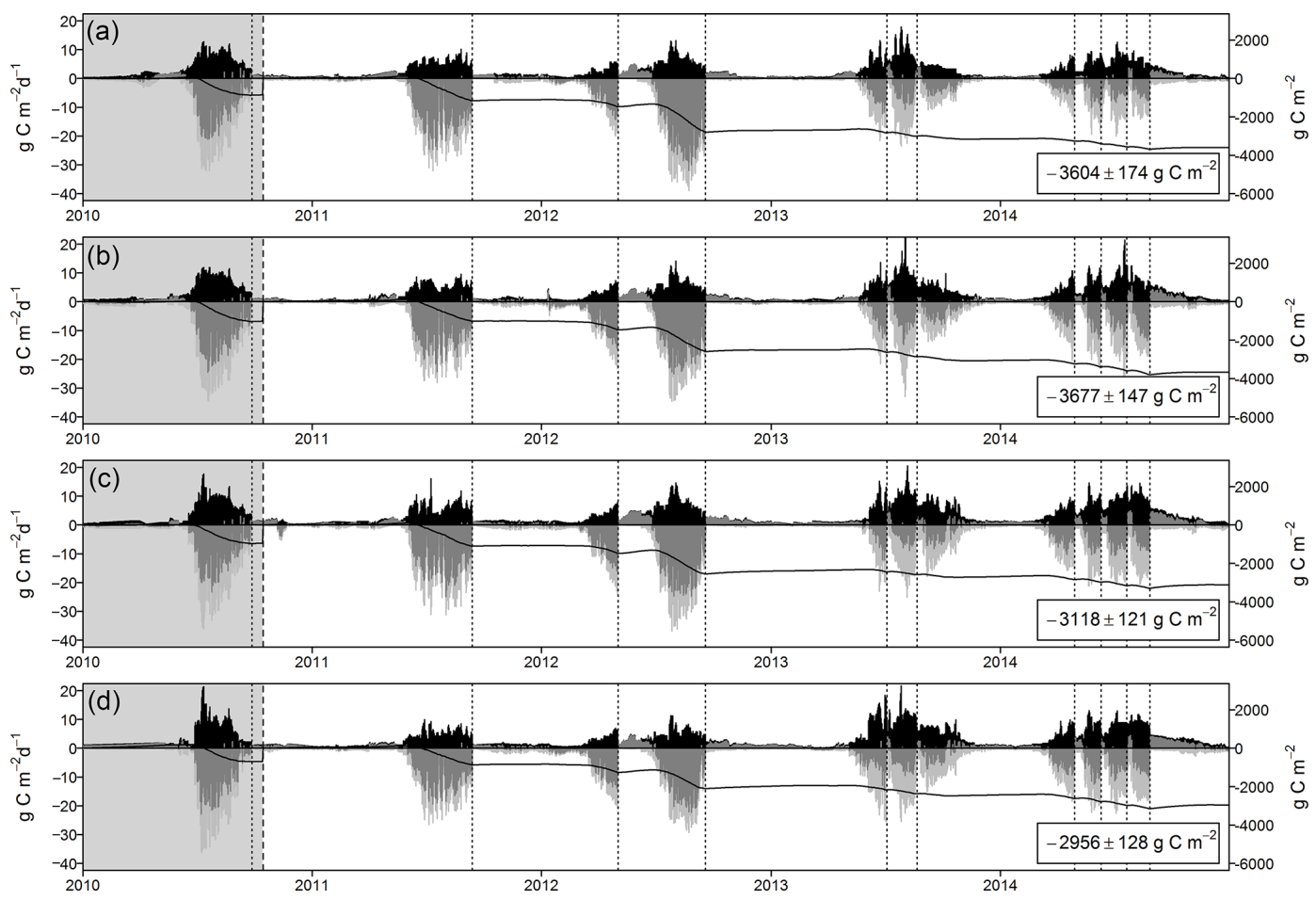

Figure 3. Time series of $\mathrm{CO}_{2}$ exchange (a-d) for the four chambers of the AC system during the study period from 2010 to 2014 . $R$ eco

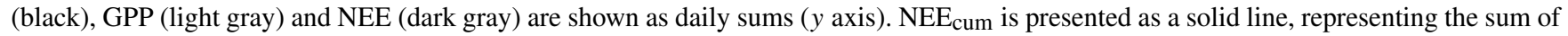
continuously accumulated daily NEE values (secondary $y$ axis). The presented values display cumulative NEE following soil manipulation to the end of 2014. Note the different scales of the $y$ axes. The gray shaded area represents the period prior to soil manipulation. The dashed vertical line indicates the soil manipulation. Dotted lines represent harvest events.

are shown in Fig. 5. Differences in NECB were in general less pronounced during the non-growing season compared to the growing season. During the non-growing season, differences were mainly driven by differences in $R_{\text {eco }}$ rather than GPP or NPP shoot. This changed at the beginning of the growing season when NECB responded to changes in cumulative NEE and $\mathrm{NPP}_{\text {shoot }}$. Hence, up to $79 \%$ of the standard deviation of estimated annual NECB developed during the period of maximum plant growth. Except for the lower middle chamber position, alfalfa seemed to counterbalance spatial differences in NECB that developed during previous years (Fig. 5).

Annual NECB values derived by the $\mathrm{C}$ budget method are presented in Table 1. Theron-based highest annual SOC gains were obtained in 2012 for winter fodder rye and sorghumSudan grass, reaching an average of $474 \mathrm{~g} \mathrm{C} \mathrm{m}^{-2} \mathrm{yr}^{-1}$. In contrast, maize cultivation during 2011 was characterized by $\mathrm{C}$ losses between 59 and $169 \mathrm{~g} \mathrm{C} \mathrm{m}^{-2} \mathrm{yr}^{-1}$. However, prior to soil manipulation, maize showed an average SOC gain of $102 \mathrm{~g} \mathrm{C} \mathrm{m}^{-2} \mathrm{yr}^{-1}$.

\subsection{Soil resampling method}

As a result of soil translocation in 2010, initially measured $\mathrm{SOC}_{\mathrm{Ap}}$ stocks increased by an average of $780 \mathrm{~g} \mathrm{C} \mathrm{m}^{-2}$. How- ever, due to the lower $\mathrm{C}$ content of the translocated topsoil material $(0.76 \%)$, the $\mathrm{SOC}_{\mathrm{Ap}}$ content of the measurement site dropped by $10-14 \%$ after soil manipulation (Table 1). Significant differences (paired $t$ test; $t=-2.48, p<0.09$ ), which showed an increase in $\mathrm{SOC}_{\mathrm{Ap}}$ of up to $11 \%$, were found between $\mathrm{SOC}_{\mathrm{Ap}}$ stocks measured in 2010 and 2014. Three out of the four chamber positions showed a $\mathrm{C}$ gain during the 4 measurement years following soil manipulation. $\mathrm{C}$ gains were similar for the upper and lower chamber positions, but lower for the upper middle position. No change in SOC was obtained in the case of the lower middle (Fig. 5, Fig. 6) chamber position.

\subsection{Method comparison}

Average annual $\triangle \mathrm{SOC}$ and NECB values for the soil resampling and $\mathrm{C}$ budget method, respectively, are shown in Fig. 6. $\triangle \mathrm{SOC}$ and NECB showed a good overall agreement, with similar tendencies and magnitudes (Fig. 6). Irrespective of the applied method, significant differences were found between SOC stocks measured directly after soil manipulation in 2010 and SOC stocks measured in 2014. Following soil manipulation, both methods revealed similar tendencies in site and chamber-specific changes in SOC (Fig. 6). Both methods indicated a clear $\mathrm{C}$ gain for three out of the four 

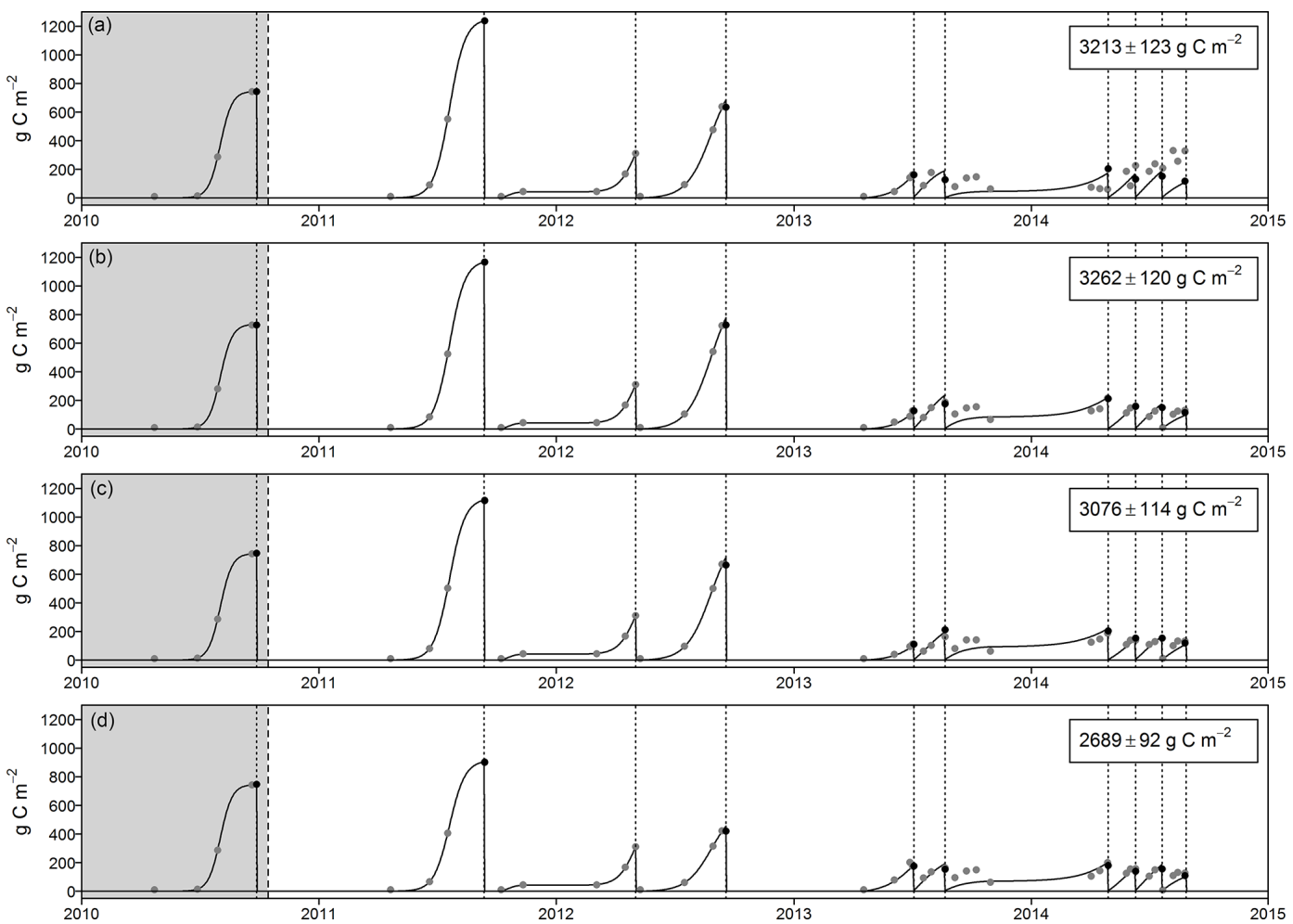

Figure 4. Time series of modeled aboveground biomass development $\left(\mathrm{NPP}_{\text {shoot }}\right)(\mathbf{a}-\mathbf{d})$ for the four chambers of the AC system during the study period from 2010 to 2014. $\mathrm{NPP}_{\text {shoot }}$ is shown as cumulative values. The presented values display cumulative $\mathrm{NPP}_{\text {shoot }}$ following soil manipulation to the end of 2014. The biomass model is based on biomass sampling (2010-2012) and LAI measurements taken once every 2 weeks (2013-2014) during crop growth (gray dots). C removal due to chamber harvests is shown by black dots. The gray shaded area represents the period prior to soil manipulation. The dashed vertical line indicates the soil manipulation. Dotted lines represent harvest events.

chamber positions. $\mathrm{C}$ gains derived by the $\mathrm{C}$ budget method were similar for the upper, upper middle and lower chamber positions. By contrast, $\mathrm{C}$ gains derived by the soil resampling method were slightly but not significantly lower (paired $t$ test; $t=-1.23, p>0.30$ ). This was most pronounced for the upper middle chamber position. No change in SOC and only a minor gain in $\mathrm{C}$ were observed for the lower middle chamber position according to both methods. Differences between chamber positions indicate the presence of small-scale spatial $\triangle \mathrm{SOC}$ dynamics typical of soils.

\section{Discussion}

\subsection{Accuracy and precision of applied methods}

Despite the similar magnitude and tendencies of the observed NECB and $\triangle S O C$ values, both methods were subject to numerous sources of uncertainty, representing the different concepts they are based on (see introduction). These errors affect the accuracy and precision of observed NECB and $\triangle$ SOC values differently, which might help to explain differences between the soil resampling and the $\mathrm{C}$ budget method.
The soil resampling method is characterized by high measurement precision, which allows for the detection of relatively small changes in SOC. Related uncertainty in derived spatial and temporal $\triangle \mathrm{SOC}$ dynamics is therefore mainly attributed to the measurement accuracy, affected by sampling strategy and design (Batjes and van Wesemael, 2015; De Gruijter et al., 2006). This includes (i) the spatial distribution of collected samples, (ii) the sampling frequency, (iii) the sampling depth and (iv) whether different components of soil organic matter (SOM) are excluded prior to analyses. The first aspect determines the capability of detecting the inherent spatial differences in SOC stocks. This allows the conclusion that point measurements do not necessarily represent AC measurements, which integrate over the spatial variability within their basal area. The second aspect defines the temporal resolution, even though the soil resampling method is not able to perfectly separate spatial from temporal variability because repeated soil samples are biased by inherent spatial variability of the measurement site. The third aspect sets the vertical system boundary, which is often limited because only topsoil horizons are sampled within a number of soil monitoring networks (Van Wesemael et al., 2011) and repeated soil inventories (Leifeld et al., 2011). Similarly, the 
fourth aspect defines which components of SOM are specifically analyzed. Usually, coarse organic material is discarded prior to analysis (Schlichting et al., 1995) and therefore total SOC is not assessed (e.g., roots, harvest residues).

In comparison, the $\mathrm{C}$ budget method considers any type of organic material present in soil by integrating over the total soil depth. As a result, both methods have a different validity range and area, which makes direct quantitative comparison more difficult. This may explain the higher uptake reported for three out of four chamber positions in the case of the $\mathrm{C}$ budget method.

In contrast to the soil resampling method, we postulate a higher accuracy and a lower precision in the case of the ACbased $\mathrm{C}$ budget method. The reasons for this include a number of potential errors affecting especially the measurement precision of the $\mathrm{AC}$ system, whereas over a constant area and maximum soil depth, integrated $\mathrm{AC}$ measurements increase measurement accuracy. First, it is currently not clear whether microclimatological and ecophysiological disturbances due to chamber deployment, such as the alteration of temperature, humidity, pressure, radiation and gas concentration, may result in biased C flux rate estimates (Juszczak et al., 2013; Kutzbach et al., 2007; Lai et al., 2012; Langensiepen et al., 2012). Second, uncertainties related to performed flux separation and gap-filling procedures may influence the obtained annual gaseous $\mathrm{C}$ exchange (Gomez-Casanovas et al., 2013; Görres et al., 2014; Moffat et al., 2007; Reichstein et al., 2005). Although continuous operation of the AC system should allow for direct derivation of $\mathrm{C}$ budgets from measured $\mathrm{CO}_{2}$ exchange and annual yields, in practice, data gaps always occur. To fill the measurement gaps, temperatureand PAR-dependent models are derived and used to calculate $R_{\text {eco }}$ and GPP, respectively (Hoffmann et al., 2015). Due to the transparent chambers used, modeled $R_{\text {eco }}$ is solely based on nighttime measurements. Hence, systematic differences between nighttime and daytime $R_{\text {eco }}$ will yield an over- or underestimation of modeled $R_{\text {eco }}$. Because modeled $R_{\text {eco }}$ is used to calculate GPP fluxes, GPP will be affected in a similar manner. However, the systematic over- or underestimation of fluxes in both directions may counterbalance the computed NEE, and estimated $\mathrm{C}$ budgets may be unaffected. Third, the development of $\mathrm{NPP}_{\text {shoot }}$ underneath the chamber might be influenced by the permanently installed AC system. Fourth, several minor components such as leaching losses of DIC and DOC, $\mathrm{C}$ transport via runoff and atmospheric $\mathrm{C}$ deposition were not considered within the applied budgeting approach (see also Sect. 2.7).

Despite the uncertainties mentioned above, error estimates for annual NEE in this study are within the range of errors presented for annual NEE estimates derived from EC measurements (30 to $50 \mathrm{~g} \mathrm{C} \mathrm{m}^{-2} \mathrm{yr}^{-1}$ ) (e.g., Baldocchi, 2003; Dobermann et al., 2006; Hollinger et al., 2005) and below the minimum detectable difference reported for most repeated soil inventories (e.g., Batjes and Van Wesemael, 2015;
Knebl et al., 2015; Necpálová et al., 2014; Saby et al., 2008; Schrumpf et al., 2011; VandenBygaart, 2006).

\subsection{Plausibility of observed $\Delta \mathrm{SOC}$}

Both the soil resampling and the $\mathrm{C}$ budget method showed $\mathrm{C}$ gains during the 4 years following soil manipulation. A number of authors calculated additional $\mathrm{C}$ sequestration due to soil erosion (Berhe et al., 2007; Dymond, 2010; VandenBygaart et al., 2015; Yoo et al., 2005), which was explained by the burial of replaced $\mathrm{C}$ at depositional sites and dynamic replacement at eroded sites (e.g., Doetterl et al., 2016). This is in accordance with erosion-induced $\mathrm{C}$ sequestration postulated by Berhe and Kleber (2013) and Van Oost et al. (2007), for example. In addition, observed $C$ sequestration could also be a result of the manipulation-induced saturation deficit in SOC. By adding topsoil material from an eroded unsaturated hillslope soil, the capacity and efficiency of sequestering $\mathrm{C}$ was theoretically increased (Stewart et al., 2007). Hence, additional $\mathrm{C}$ was stored at the measurement site. This might be due to physicochemical processes, such as physical protection in macro- and microaggregates (Six et al., 2002) or chemical stabilization by clay and iron minerals (Kleber et al., 2015).

Irrespective of the similar $\mathrm{C}$ gain observed by both methods, crop-dependent differences in NECB and thus $\triangle \mathrm{SOC}$ were only revealed by the $\mathrm{C}$ budget method. The reason is the higher temporal resolution of $\mathrm{AC}$-derived $\mathrm{C}$ budgets, displaying daily $\mathrm{C}$ losses and gains. Observed crop-dependent differences in NECB are in accordance with Kutsch et al. (2010), Jans et al. (2010), Hollinger et al. (2005) and Verma et al. (2005), for example, who reported comparable EC-derived $\mathrm{C}$ balances for, inter alia, maize, sorghum and alfalfa.

In 2012, substantial positive annual NECB values were observed. Due to low precipitation during May and June, germination and plant growth of sorghum-Sudan grass was delayed (Fig. 4). As a result, the reproductive phenological stage was drastically shortened. This reduced C losses prior to harvest due to higher $R_{\text {eco }}$ : GPP ratios (Wagle et al., 2015). In addition, the presence of cover crops during spring and autumn could have increased SOC, as reported by Lal et al. (2004), Ghimire et al. (2014) and Sainju et al. (2002). No additional C sequestration was observed for alfalfa in 2013 and 2014 or for the lower middle chamber position, which acted neither as a net $\mathrm{C}$ source nor sink (Table 1, Fig. 5). This opposes the assumption of increased $\mathrm{C}$ sequestration by perennial grasses (Paustian et al., 1997) or perennial crops (Zan et al., 2001). However, NEE estimates of alfalfa were within the range of -100 to $-400 \mathrm{~g} \mathrm{C} \mathrm{m}^{-2}$, which is typical for forage crops (Lolium, alfalfa, etc.) in different agro-ecosystems (Bolinder et al., 2012; Byrne et al., 2005; Gilmanov et al., 2013; Zan et al., 2001). In addition, Alberti et al. (2010) reported a soil C loss of $>170 \mathrm{~g} \mathrm{C} \mathrm{m}^{-2}$ after crop conversion from continuous 


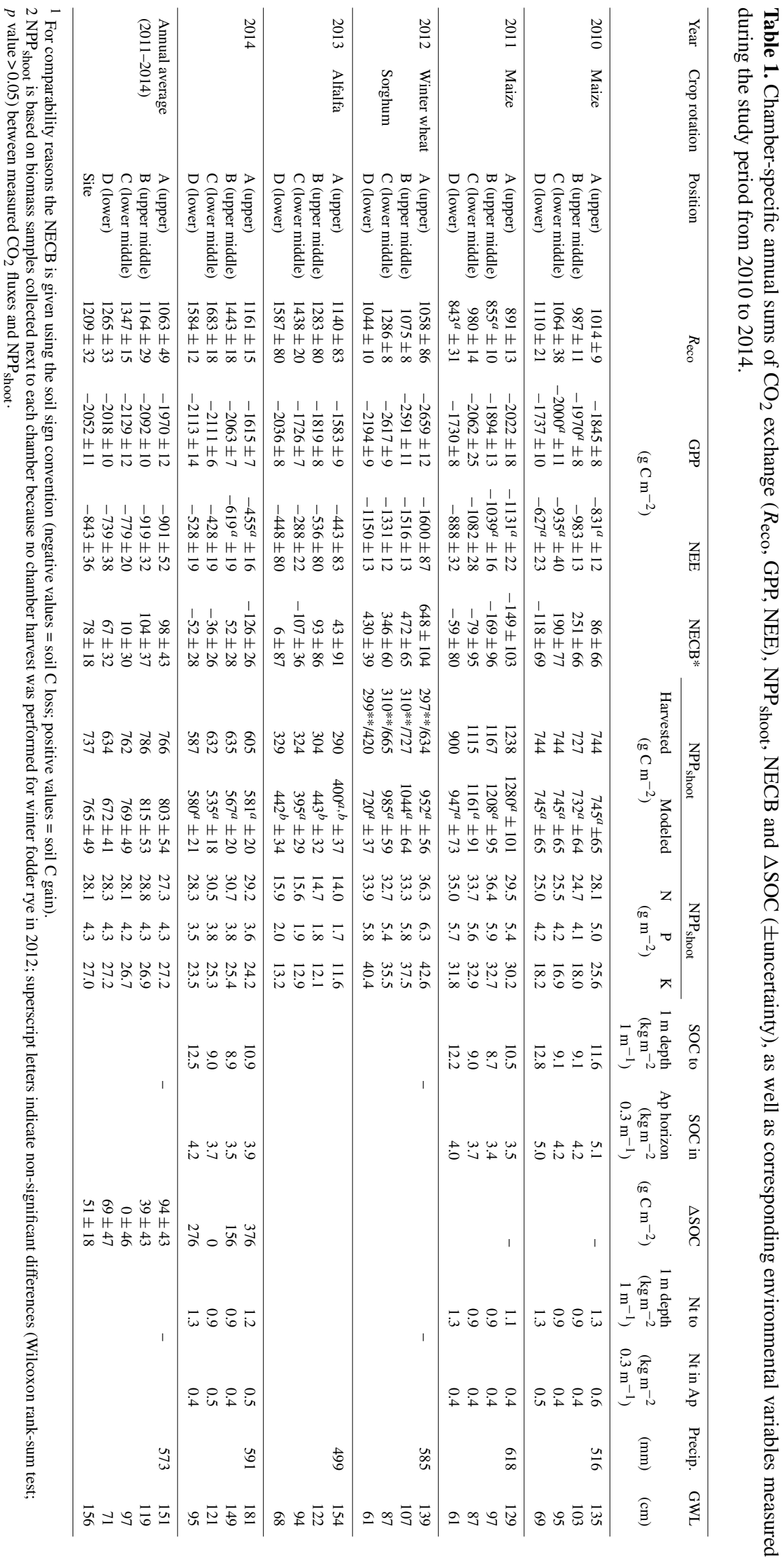



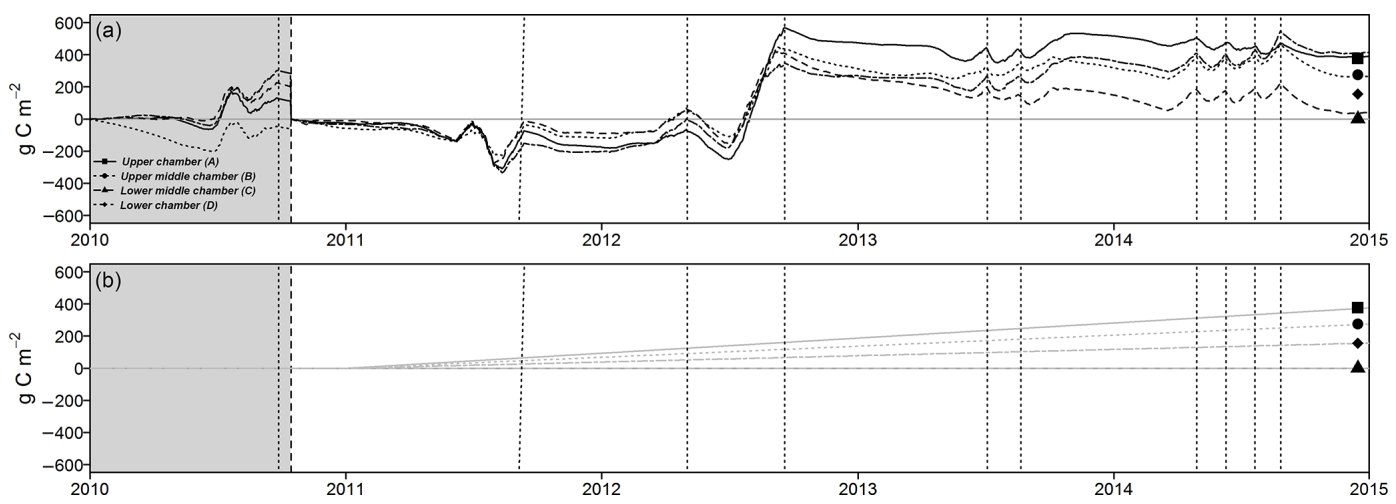

Figure 5. Temporal and spatial dynamics in cumulative NECB and $\triangle \mathrm{SOC}$ throughout the study period based on (a) the C budget method (measured-modeled, black lines) and (b) the soil resampling method (linear interpolation, gray lines), respectively. The gray shaded area represents the period prior to soil manipulation. The dashed vertical line indicates the soil manipulation. Dotted lines represent harvest events. Temporal dynamics in NECB revealed by the $\mathrm{C}$ budget method allow for the identification of periods that are most important for changes in SOC. Major spatial deviation occurred during the maximum plant growth period (May to September). The proportion (\%) of these periods with respect to the standard deviation of estimated annual NECB accounted for up to $79 \%$.

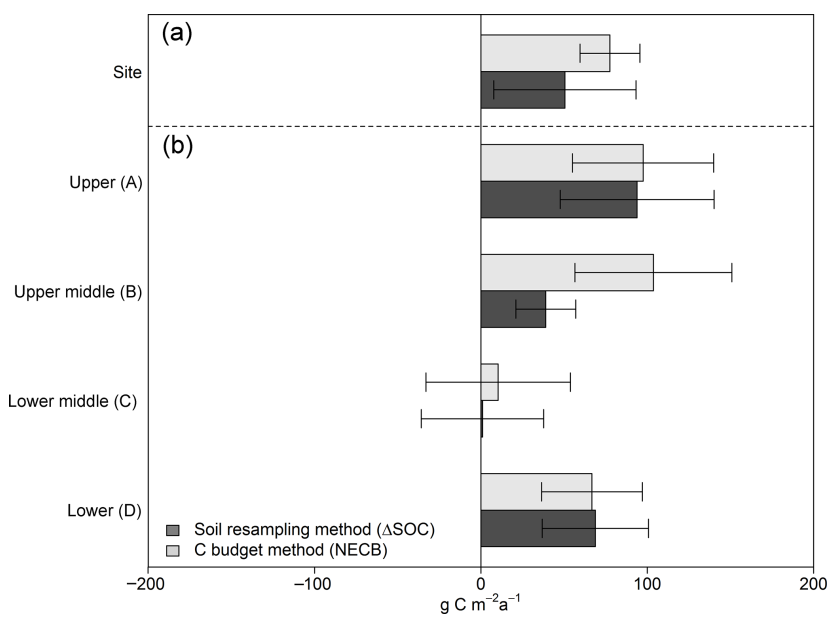

Figure 6. Average annual $\triangle \mathrm{SOC}$ observed after soil manipulation (April 2011 to December 2014) by soil resampling and the C budget method for (a) the entire measurement site and (b) single chamber positions within the measured transect. $\triangle \mathrm{SOC}$ represents the change in carbon storage, with positive values indicating $\mathrm{C}$ sequestration and negative values indicating $\mathrm{C}$ losses. Error bars display estimated uncertainty for the $\mathrm{C}$ budget method and the analytical error of $\pm 5 \%$ for the soil resampling method. A performed Wilcoxon rank-sum test showed no significant difference between NECB and $\triangle \mathrm{SOC}$ values obtained by both methodological approaches for all four chambers ( $p$ value $=0.25$ ).

maize to alfalfa, concluding that no effective $\mathrm{C}$ sequestration occurs in the short term.

Regardless of the crop type, the AC-derived dynamic NECB values showed that up to $79 \%$ of the standard deviation of estimated annual NECB occurred during the growing season and the main plant growth period from the beginning of July to the end of September.

\section{Conclusions}

We confirmed that $\mathrm{AC}$-based $\mathrm{C}$ budgets are in principle able to detect small-scale spatial differences in NECB and might thus be used to detect spatial heterogeneity of $\triangle \mathrm{SOC}$, similar to the soil resampling method. However, compared to soil resampling, AC-based $\mathrm{C}$ budgets also reveal short-term temporal dynamics (Fig. 5). In addition, AC-based NECB values corresponded well with tendencies and magnitude of $\triangle \mathrm{SOC}$ values observed by the repeated soil inventory. The period of maximum plant growth was identified as being most important for the development of spatial differences in annual NECB. For upscaling purposes of the presented results, further environmental drivers, processes and mechanisms determining $\mathrm{C}$ allocation in space and time within the plant-soil system need to be identified. This type of an approach will be pursued in the future within the CarboZALF experimental setup (Sommer et al., 2016; Wehrhan et al., 2016). Moreover, the AC-based $\mathrm{C}$ budget method opens up new prospects for clarifying unanswered questions, such as what the influence is of plant development or erosion on NECB and estimates of $\triangle \mathrm{SOC}$ based thereon.

\section{Data availability}

The data referred to in this study is publicly accessible at doi:10.4228/ZALF.2017.322 (Hoffmann et al., 2017). 
Appendix A: Management information and weather conditions

Table A1. Management information regarding the study period from 2010 to 2014. Bold rows indicate coverage by chamber measurements.

\begin{tabular}{|c|c|c|c|}
\hline Crop & Treatment & Details & Date \\
\hline \multirow{4}{*}{$\begin{array}{l}\text { Winter fodder rye } \\
\text { (Secale cereale) }\end{array}$} & Chamber dismounting & & $10 / 04 / 2010$ \\
\hline & Herbicide application & Roundup $\left(2 \mathrm{Lha}^{-1}\right)$ & $19 / 04 / 2010$ \\
\hline & Fertilization & $\begin{array}{l}\text { KAS }\left(160 \mathrm{~kg} \mathrm{ha}^{-1} \mathrm{~N}\right), 110 \mathrm{~kg} \mathrm{ha}^{-1} \mathrm{P} 2 \mathrm{O} 5,190 \mathrm{~kg} \mathrm{ha}^{-1} \mathrm{~K} 2 \mathrm{O} \text {, } \\
22 \mathrm{~kg} \mathrm{ha}^{-1} \mathrm{~S}^{-1} 27 \mathrm{~kg} \mathrm{ha}^{-1} \mathrm{MgO}\end{array}$ & $23 / 04 / 2010$ \\
\hline & Ploughing & Chisel plough & $23 / 04 / 2010$ \\
\hline \multirow[t]{4}{*}{ Silage maize (Zea mays) } & Sowing & 10 seeds $\mathrm{m}^{-2}$ & $23 / 04 / 2010$ \\
\hline & Chamber installation & & $04 / 05 / 2010$ \\
\hline & Herbicide application & Zintan Platin Pack & $26 / 05 / 2010$ \\
\hline & Harvest & & $19 / 09 / 2010$ \\
\hline \multirow[t]{5}{*}{ Bare soil } & Chamber dismounting & & $20 / 09 / 2010$ \\
\hline & Chamber installation & & 27/10/2010 \\
\hline & Chamber dismounting & & $05 / 04 / 2011$ \\
\hline & Fertilization & $\begin{array}{l}110 \mathrm{~kg} \mathrm{ha}^{-1} \mathrm{P} 2 \mathrm{O} 5,190 \mathrm{~kg} \mathrm{ha}^{-1} \mathrm{~K} 2 \mathrm{O}, 22 \mathrm{~kg} \mathrm{ha}^{-1} \mathrm{~S} \text { and } 27 \\
\mathrm{~kg} \mathrm{ha}^{-1} \mathrm{MgO}\end{array}$ & $06 / 04 / 2011$ \\
\hline & Ploughing & Chisel plough & $21 / 04 / 2011$ \\
\hline \multirow[t]{5}{*}{ Silage maize (Zea mays) } & Sowing & 10 seeds $\mathrm{m}^{-2}$ & $21 / 04 / 2011$ \\
\hline & Herbicide application & Gardo Gold Pack, $3.5 \mathrm{~L} \mathrm{ha}^{-1}$ & $27 / 04 / 2011$ \\
\hline & Fertilization & KAS $\left(160 \mathrm{~kg} \mathrm{ha}^{-1} \mathrm{~N}\right)$ & $03 / 05 / 2011$ \\
\hline & Chamber installation & & $04 / 05 / 2011$ \\
\hline & Harvest & & $13 / 09 / 2011$ \\
\hline \multirow[t]{2}{*}{ Bare soil } & Chamber dismounting & & $13 / 09 / 2011$ \\
\hline & Ploughing & Chisel plough & $30 / 09 / 2011$ \\
\hline \multirow{4}{*}{$\begin{array}{l}\text { Winter fodder rye } \\
\text { (Secale cereale) }\end{array}$} & Sowing & 270 seeds $\mathrm{m}^{-2}$ & $30 / 09 / 2011$ \\
\hline & Chamber installation & & 05/10/2011 \\
\hline & Fertilization & KAS $\left(80 \mathrm{~kg} \mathrm{ha}^{-1} \mathrm{~N}\right)$ & $06 / 03 / 2012$ \\
\hline & Harvest & & $02 / 05 / 2012$ \\
\hline \multirow[t]{2}{*}{ Bare soil } & Chamber dismounting & & $02 / 05 / 2012$ \\
\hline & Ploughing & & $08 / 05 / 2012$ \\
\hline \multirow{6}{*}{$\begin{array}{l}\text { Sorghum-Sudan grass } \\
(\text { Sorghum bicolor } \times \text { sudanese })\end{array}$} & Sowing & $30{\text { seeds } \mathrm{m}^{-2}}^{-2}$ & 09/05/2012 \\
\hline & Fertilization & $\begin{array}{l}\text { KAS }\left(100 \mathrm{~kg} \mathrm{ha}^{-1} \mathrm{~N}\right) \text {, Kieserite }\left(100 \mathrm{~kg} \mathrm{ha}^{-1}\right), 220 \mathrm{~kg} \mathrm{ha}^{-1} \\
\text { P2O5, } 190 \mathrm{~kg} \mathrm{ha}^{-1} \mathrm{~K} 2 \mathrm{O}\end{array}$ & $14 / 05 / 2012$ \\
\hline & Chamber installation & & $22 / 05 / 2012$ \\
\hline & Replanting & & 29/05/2012 \\
\hline & Herbicide application & Gardo Gold Pack (3 L ha $\left.{ }^{-1}\right)$, Buctril $\left(1.5 \mathrm{~L} \mathrm{ha}^{-1}\right)$ & $12 / 07 / 2012$ \\
\hline & Harvest & & $18 / 09 / 2012$ \\
\hline \multirow[t]{2}{*}{ Bare soil } & Chamber dismounting & & $19 / 09 / 2012$ \\
\hline & Ploughing & Chisel plough & $09 / 10 / 2012$ \\
\hline \multirow[t]{4}{*}{ Winter triticale (Triticosecale) } & Sowing & 400 seeds $\mathrm{m}^{-2}$ & 09/10/2012 \\
\hline & Chamber installation & & $19 / 10 / 2012$ \\
\hline & Chamber dismounting & & 20/09/2012 \\
\hline & Chamber installation & & 17/10/2012 \\
\hline \multirow[t]{11}{*}{ Luzerne (Medicago sativa) } & Ploughing; fertilization & Chisel plough; $44 \mathrm{~kg} \mathrm{ha}^{-1} \mathrm{K2O}, 48.4 \mathrm{~kg} \mathrm{ha}^{-1} \mathrm{P} 40$ & $15 / 04 / 2013$ \\
\hline & Sowing & $22 \mathrm{kgha}^{-1}$ & $18 / 04 / 2013$ \\
\hline & Harvest (first cut) & & $04 / 07 / 2013$ \\
\hline & Fertilization & $88 \mathrm{~kg} \mathrm{ha}^{-1} \mathrm{K2O}$ & $10 / 07 / 2013$ \\
\hline & Harvest (second cut) & & $21 / 08 / 2013$ \\
\hline & Fertilization & $200 \mathrm{~kg} \mathrm{ha}^{-1} \mathrm{~K} 2 \mathrm{O}, 110 \mathrm{~kg} \mathrm{ha}^{-1} \mathrm{P} 2 \mathrm{O5}$ & $27 / 02 / 2014$ \\
\hline & Harvest (first cut) & & 29/04/2014 \\
\hline & Harvest (second cut) & & $10 / 06 / 2014$ \\
\hline & Harvest (third cut) & & 21/07/2014 \\
\hline & Harvest (fourth cut) & & 27/08/2014 \\
\hline & Chamber dismounting & & 28/08/2014 \\
\hline
\end{tabular}


Figure A1 shows the development of important environmental variables throughout the study period (January 2010December 2014). In general, weather conditions were similarly warm $\left(8.7^{\circ} \mathrm{C}\right)$ but also wetter $(562 \mathrm{~mm})$ compared to the long-term average $\left(8.6^{\circ} \mathrm{C}, 485 \mathrm{~mm}\right)$. Temperature and precipitation were characterized by distinct interannual and intra-annual variability. The highest annual air temperature was measured in $2014\left(9^{\circ} \mathrm{C}\right)$. The highest annual precipitation was recorded during $2011(616 \mathrm{~mm})$. Lower annual mean air temperature and comparatively drier weather conditions were recorded in $2010\left(7.7^{\circ} \mathrm{C}, 515 \mathrm{~mm}\right)$ and 2013 $\left(8.5^{\circ} \mathrm{C}, 499 \mathrm{~mm}\right)$. Clear seasonal patterns were observed for air temperature. The daily mean air temperature at a height of $200 \mathrm{~cm}$ varied between $-18.8^{\circ} \mathrm{C}$ in February 2012 and $26.3^{\circ} \mathrm{C}$ in July 2010 . Rainfall was highly variable and mainly occurred during the growing season (55 to $93 \%$ ), with pronounced heavy rain events during summer periods, exceeding $50 \mathrm{~mm} \mathrm{~d}^{-1}$. Despite a rather wet summer, only $67 \mathrm{~mm}$ was measured in March and April 2012, the driest spring period within the study, resulting in late germination and reduced plant growth. Annual GWL differed by up to $77 \mathrm{~cm}$ along the chamber transect and followed precipitation patterns. Seasonal dynamics were characterized by a lower GWL within the growing season $(1.10 \mathrm{~m})$ and enhanced GWL during the non-growing season $(0.85 \mathrm{~m})$. From a short-term perspective, GWL was closely related to single rainfall events. Hence, a GWL of $0.10 \mathrm{~m}$ was measured immediately after a heavy rainfall event in July 2011, whereas the lowest GWL occurred during the dry spring in 2010. From August 2013 to December 2014, the GWL was too low to apply the principal of hydrostatic equilibrium; therefore, the groundwater table depth $(>235 \mathrm{~cm})$ had to be used as a proxy.

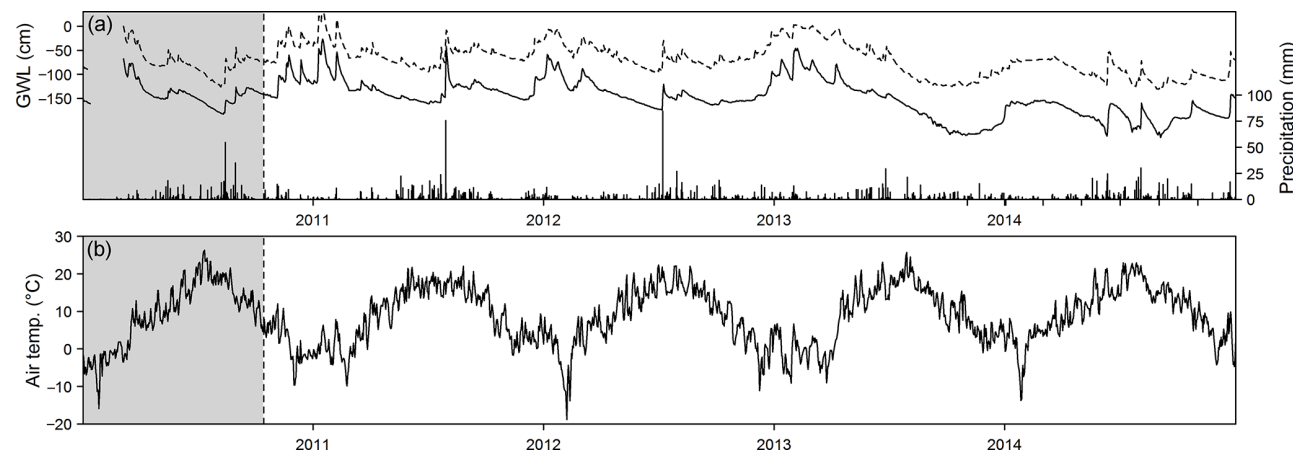

Figure A1. Time series of recorded environmental conditions throughout the study period from 2010 to 2014. Daily precipitation and GWL are shown for the upper (solid line) and lower (dashed line) chamber positions in the upper panel (a). The lower panel (b) shows the mean daily air temperature. The gray shaded area represents the period prior to soil manipulation. The dashed vertical line indicates the soil manipulation. 
Competing interests. The authors declare that they have no conflict of interest.

Acknowledgements. This work was supported by the Brandenburg Ministry of Infrastructure and Agriculture (MIL), who financed the land purchase; the Federal Agency for Renewable Resources (FNR), who co-financed the AC system and the interdisciplinary research project CarboZALF. The authors want to express their special thanks to Peter Rakowski for excellent operational and technical maintenance during the study period as well as to the employees of the ZALF research station, Dedelow, for establishing and maintaining the CarboZALF-D field trial.

Edited by: S. Fontaine

Reviewed by: two anonymous referees

\section{References}

Alberti, G., Delle Vedove, G. D., Zuliani, M., Peressotti, A., Castaldi, S., and Zerbi, G.: Changes in $\mathrm{CO}_{2}$ emissions after crop conversion from continuous maize to alfalfa, Agric. Ecosyst. Environ., 136, 139-147, 2010.

Baldocchi, D. D.: Assessing the eddy covariance technique for evaluating carbon dioxide exchange rates of ecosystems: past, present and future, Glob. Change Biol., 9, 479-492, 2003.

Batjes, N. H. and van Wesemael, B.: Measuring and monitoring soil carbon, in: Soil Carbon: Science, Management and Policy for Multiple Benefits, edited by: Banwart, S. A., Noellemeyer, E., and Milne, E., SCOPE Series 71. CABI, Wallingford, UK, 188201, 2015.

Berhe, A. A. and Kleber, M.: Erosion, deposition, and the persistence of soil organic matter: mechanistic consideration and problems with terminology, Earth Surf. Proc. Landforms, 38, 908912, 2013.

Berhe, A. A., Harte, J., Harden, J. W., and Torn, M. S.: The significance of the erosion-induced terrestrial carbon sink, BioScience, 57, 337-346, 2007.

Bolinder, M. A., Kätterer, T., Andrén, O., and Parent, L. E.: Estimating carbon inputs to soil in forage-based crop rotations and modeling the effects on soil carbon dynamics in a Swedish longterm field experiment, Can. J. Soil. Sci., 92, 821-833, 2012.

Byrne, K. A., Kiely, G., and Leahy, P.: $\mathrm{CO}_{2}$ fluxes in adjacent new and permanent temperate grasslands, Agric. For. Meteorol., 135, 82-92, 2005.

Chen, L., Smith, P., and Yang, Y.: How has soil carbon stock changed over recent decades?, Glob. Change Biol., 21, 31973199, 2015.

Conant, R. T., Ogle, S. M., Paul, E. A., and Paustian, K.: Measuring and monitoring soil organic carbon stocks in agricultural lands for climate mitigation, Front. Ecol. Environ., 9, 169-173, 2011.

Culman, S. W., Snapp, S. S., Green, J. M., and Gentry, L. E.: Shortand long-term labile soil carbon and nitrogen dynamics reflect management and predict corn agronomic performance, Agron. J., 105, 493-502, 2013.

Davidson, E. A., Savage, K., Verchot, L. V., and Navarro, R.: Minimizing artifacts and biases in chamber-based measurements of soil respiratio, Agric. For. Meteorol., 113, 21-37, 2002.
De Gruijter, J. J., Brus, D. J., Bierkens, M. F. P., and Knotters, M.: Sampling for Natural Resource Monitoring, Springer Verlag, Berlin, 2006.

Deumlich, D., Rogasik, H., Hierold, W., Onasch, I., Völker, L., and Sommer, M.: The CarboZALF-D manipulation experiment - experimental design and SOC patterns, Int. J. Environ. Agric. Res., 3, 40-50, 2017.

Dobermann, A. R., Walters, D. T., Baker, J. M.: Comment on "Carbon budget of mature no-till ecosystem in north central region of the United States", Agric. For. Meteorol., 136, 83-84, 2006.

Doetterl, S., Berhe, A. A., Nadeu, E., Wang, Z., Sommer, M., and Fiener, P.: Erosion, deposition and soil carbon: a review of process-level controls, experimental tools and models to address C cycling in dynamic landscapes, Earth Sci. Rev., 154, 102-122, 2016.

Dymond, J. R.: Soil erosion in New Zealand is a net sink of $\mathrm{CO}_{2}$, Earth Surf. Proc. Landforms, 35, 1763-1772, doi:10.1002/esp.2014, 2010.

Eickenscheidt, T., Freibauer, A., Heinichen, J., Augustin, J., and Drösler, M.: Short-term effects of biogas digestate and cattle slurry application on greenhouse gas emissions affected by $\mathrm{N}$ availability from grasslands on drained fen peatlands and associated organic soils, Biogeosciences, 11, 6187-6207, doi:10.5194/bg-11-6187-2014, 2014.

Elsgaard, L., Görres, C., Hoffmann, C. C., Blicher-Mathiesen, G., Schelde, K., and Petersen, S. O.: Net ecosystem exchange of $\mathrm{CO}_{2}$ and carbon balance for eight temperate organic soils under agricultural management, Agric. Ecosyst. Environ., 162, 52-67, 2012.

Foken, T.: Micrometeorology, Springer Verlag, Berlin, 2008.

Ghimire, R., Norton, J. B., and Pendall, E.: Alfalfa-grass biomass, soil organic carbon, and total nitrogen under different management approaches in an irrigated agroecosystem, Plant Soil, 374, 173-184, 2014.

Gilmanov, T. G., Soussana, J. F., Aires, L., Allard, V., Ammann, C., Balzarolo, M., Barcza, Z., Bernhofer, C., Campbell, C. L., Cernusca, A., Cescatti, A., Clifton-Brown, J., Dirks, B. O. M., Dore, S., Eugster, W., Fuhrer, J., Gimeno, C., Gruenwald, T., Haszpra, L., Hensen, A., Ibrom, A., Jacobs, A. F. G., Jones, M. B., Lanigan, G., Laurila, T., Lohila, A., Manca, G., Marcolla, B., Nagy, Z., Pilegaard, K., Pinter, K., Pio, C., Raschi, A., Rogiers, N., Sanz, M. J., Stefani, P., Sutton, M., Tuba, Z., Valentini, R., Williams, M. L., and Wohlfahrt, G.: Partitioning European grassland net ecosystem $\mathrm{CO}_{2}$ exchange into gross primary productivity and ecosystem respiration using light response function analysis, Agric. Ecosyst. Environ., 121, 93-120, 2007.

Gilmanov, T. G., Wylie, B. K., Tieszen, L. L., Meyers, T. P., Baron, V. S., Bernacchi, C. J., Billesbach, D. P., Burba, G. G., Fischer, M. L., Glenn, A. J., Hanan, N. P., Hatfield, J. L., Heuer, M. W., Hollinger, S. E., Howard, D. M., Matamala, R., Prueger, J. H., Tenuta, M., and Young, D. G.: $\mathrm{CO}_{2}$ uptake and ecophysiological parameters of the grain crops of midcontinent North America: estimates from flux tower measurements, Agric. Ecosyst. Environ., 164, 162-175, 2013.

Gomez-Casanovas, N., Anderson-Teixeira, K., Zeri, M., Bernacchi, C. J., DeLucia, E. H.: Gap filling strategies and error in estimating annual soil respiration, Glob. Change Biol., 19, 1941-1952, 2013. 
Görres, C.-M., Kutzbach, L., and Elsgaard, L.: Comparative modeling of annual $\mathrm{CO}_{2}$ flux of temperate peat soils under permanent grassland management, Agric. Ecosyst. Environ., 186, 6476, 2014.

Hernandez-Ramirez, G., Hatfield, J. L., Parkin, T. B., Sauer, T. J., and Prueger, J. H.: Carbon dioxide fluxes in corn-soybean rotation in the midwestern U.S.: inter- and intra-annual variations, and biophysical controls, Agric. For. Meteorol., 151, 1831-1842, 2011

Hoffmann, M., Jurisch, N., Borraz, E. A., Hagemann, U., Drösler, M., Sommer, M., and Augustin, J.: Automated modeling of ecosystem $\mathrm{CO}_{2}$ fluxes based on periodic closed chamber measurements: a standardized conceptual and practical approach, Agric. For. Meteorol., 200, 30-45, 2015.

Hoffmann, M., Jurisch, N., Garcia Alba, J., Albiac Borraz, E., Schmidt, M., Huth, V., Rogasik, H., Rieckh, H., Verch, G., Sommer, M., and Augustin, J.: Detecting small-scale spatial heterogeneity and temporal dynamics of soil organic carbon (SOC) stocks: a comparison between automatic chamber-derived $\mathrm{C}$ budgets and repeated soil inventories, Leibniz Centre for Agricultural Landscape Research (ZALF), doi:10.4228/ZALF.2017.322, 2017.

Hollinger, S. E., Bernacchi, C. J., and Meyers, T. P.: Carbon budget of mature no-till ecosystem in north central region of the United States, Agric. For. Meteorol., 130, 59-69, 2005.

IUSS Working Group WRB: World reference base for soil resources 2014, International soil classification system for naming soils and creating legends for soil maps, Update 2015, World Soil Resources Reports No. 106, FAO, Rome, 2015.

Jans, W. W. P., Jacobs, C. M. J., Kruijt, B., Elbers, J. A., Barendse, S., and Moors, E. J.: Carbon exchange of a maize (Zea mays L.) crop: influence of phenology, Agric. Ecosyst. Environ., 139, 316-324, 2010.

Juszczak, R., Humphreys, E., Acosta, M., Michalak-Galczewska, M., Kayzer, D., and Olejnik, J.: Ecosystem respiration in a heterogeneous temperate peatland and its sensitivity to peat temperature and water table depth, Plant Soil, 366, 505-520, 2013.

Kleber, M., Eusterhues, K., Keiluweit, M., Mikutta, C., Mikutta, R., and Nico, P. S.: Chapter one - Mineral-Organic associations: Formation, Properties, and relevance in soil environments, Adv. Agro., 130, 1-140, 2015.

Knebl, L., Leithold, G., and Brock, C.: Improving minimum detectable differences in the assessment of soil organic matter change in short-term field experiments, J. Plant Nutr. Soil Sci., 178, 35-42, 2015.

Koskinen, M., Minkkinen, K., Ojanen, P., Kämäräinen, M., Laurila, T., and Lohila, A.: Measurements of $\mathrm{CO}_{2}$ exchange with an automated chamber system throughout the year: challenges in measuring night-time respiration on porous peat soil, Biogeosciences, 11, 347-363, doi:10.5194/bg-11-347-2014, 2014.

Kutsch, W. L., Aubinet, M., Buchmann, N., Smith, P., Osborne, B., Eugster, W., Wattenbach, M., Schrumpf, M., Schulze, E. D., Tomelleri, E., Ceschia, E., Bernhofer, C., Béziat, P., Carrara, A., Di Tommasi, P., Grünwald, T., Jones, M., Magliulo, V., Marloie, O., Moureaux, C., Olioso, A., Sanz, M. J., Saunders, M., Søgaard, H., and Ziegler, W.: The net biome production of full crop rotations in Europe, Agric. Ecosyst. Environ., 139, 336345,2010
Kutzbach, L., Schneider, J., Sachs, T., Giebels, M., Nykänen, H., Shurpali, N. J., Martikainen, P. J., Alm, J., and Wilmking, M.: $\mathrm{CO}_{2}$ flux determination by closed-chamber methods can be seriously biased by inappropriate application of linear regression, Biogeosciences, 4, 1005-1025, doi:10.5194/bg4-1005-2007, 2007.

Lai, D. Y. F., Roulet, N. T., Humphreys, E. R., Moore, T. R., and Dalva, M.: The effect of atmospheric turbulence and chamber deployment period on autochamber $\mathrm{CO}_{2}$ and $\mathrm{CH}_{4}$ flux measurements in an ombrotrophic peatland, Biogeosciences, 9, 33053322, doi:10.5194/bg-9-3305-2012, 2012.

Lal, R., Griffin, M., Apt, J., Lave, L., and Morgan, G. M.: Managing Soil carbon, Science, 304, p. 393, 2004.

Langensiepen, M., Kupisch, M., van Wijk, M. T., and Ewert, F.: Analyzing transient closed chamber effects on canopy gas exchange for flux calculation timing, Agric. For. Meteorol., 164, 61-70, 2012.

Leiber-Sauheitl, K., Fuß, R., Voigt, C., and Freibauer, A.: High $\mathrm{CO}_{2}$ fluxes from grassland on histic Gleysol along soil carbon and drainage gradients, Biogeosciences, 11, 749-761, doi:10.5194/bg-11-749-2014, 2014.

Leifeld, J., Ammann, C., Neftel, A., and Fuhrer, J.: A comparison of repeated soil inventory and carbon flux budget to detect soil carbon stock changes after conversion from cropland to grasslands, Glob. Change Biol., 17, 3366-3375, 2011.

Leifeld, J., Bader, C., Borraz, E., Hoffmann, M., Giebels, M., Sommer, M., and Augustin, J.: Are C-loss rates from drained peatlands constant over time? The additive value of soil profile based and flux budget approach, Biogeosciences Discuss., 11, 1234112373, doi:10.5194/bgd-11-12341-2014, 2014.

Livingston, G. P. and Hutchinson, G. L.: Enclosure-based measurement of trace gas exchange: applications and sources of error, in: Methods in Ecology. Biogenic Trace Gases: Measuring Emissions from Soil and Water, edited by: Matson, P. A. and Harris, R. C., Blackwell Science, Oxford, UK, 14-51, 1995.

Lloyd, J. and Taylor, J. A.: On the temperature dependence of soil respiration, Funct. Ecol., 8, 315-323, 1994.

Luo, Y., Ahlström, A., Allison, S. D., Batjes, N. H., Brovkin, V., Carvalhais, N., Chappell, A., Ciais, P., Davidson, E. A., Finzi, A., Georgiou, K., Guenet, B., Hararuk, O., Harden, J. W., He, Y., Hopkins, F., Jiang, L., Koven, C., Jackson, R. B., Jones, C. D., Lara, M. J., Liang, J., McGuire, A. D., Parton, W., Peng, C., Randerson, J. T., Salazar, A., Sierra, C. A., Smith, M. J., Tian, H., Todd-Brown, K. E. O., Torn, M., van Groenigen, K. J., Wang, Y. P., West, T. O., Wie, Y., Wieder, W. R., Xia, J., Xu, X., Xu, X., and Zhou, T.: Toward more realistic projections of soil carbon dynamics by Earth system models, Global Biogeochem. Cy., 30, 40-56, 2016.

Moffat, A. M., Papale D., Reichstein M., Hollinger, D. Y., Richardson, A. D., Barr, A. G., Beckstein, C., Braswell, B. H., Churkina, G., Desai, A. R., Falge, E., Gove, J. H., Heimann, M., Hui, D., Jarvis, A. J., Kattge, J., Noormets, A., and Stauch, V. J.: Comprehensive comparison of gap-filling techniques for eddy covariance net carbon fluxes, Agric. For. Meteorol., 147, 209-232, 2007.

Necpálová, M., Anex Jr., R. P., Kravchenko, A. N., Abendroth, L. J., Del Grosso, S. J., Dick, W. A., Helmers, M. J., Herzmann, D., Lauer, J. G., Nafziger, E. D., Sawyer, J. E., Scharf, P. C., Strock, J. S., and Villamil, M. B.: What does it take to detect a change in soil carbon stock? A regional comparison of minimum detectable 
difference and experiment duration in the north central United States, J. Soils Water Conserv., 69, 517-531, 2014.

Paustian, K., Collins, H. P., and Paul, E. A.: Management controls on soil carbon, in: Soil Organic Matter in Temperate Agroecosystems: Long-Term Experiments in North America, edited by: Paul, E. A., Paustian, K., Elliott, E. T., and Cole, C. V., CRC Press, Boca Raton, FL, 15-50, 1997.

Poeplau, C., Bolinder, M. A., and Kätterer, T.: Towards an unbiased method for quantifying treatment effects on soil carbon in long-term experiments considering initial within-field variation, Geoderma, 267, 41-47, 2016.

Pohl, M., Hoffmann, M., Hagemann, U., Giebels, M., Albiac Borraz, E., Sommer, M., and Augustin, J.: Dynamic C and N stocks key factors controlling the $\mathrm{C}$ gas exchange of maize in heterogenous peatland, Biogeosciences, 12, 2737-2752, doi:10.5194/bg12-2737-2015, 2015.

Reichstein, M., Falge, E., Baldocchi, D., Papale, D., Aubinet, M., Berbiger, P., Bernhofer, C., Buchmann, N., Gilmanov, T., Granier, A., Grünwald, T., Havránková, K., Ilvesniemi, H., Janous, D., Knohl, A., Laurila, T., Lohila, A., Loustau, D., Metteucci, G., Meyers, T., Miglietta, F., Ourcival, J.-M., Pumpanen, J., Rambal, S., Rotenberg, E., Sanz, M., Tenhunen, J., Seufert, G., Vaccari, F., Vesala, T., Yakir, D., and Valentini, R.: On the separation of net ecosystem exchange into assimilation and ecosystem respiration: review and improved algorithm, Glob. Change Biol., 11, 1424-1439, 2005.

Rieckh, H., Gerke, H. H., and Sommer, M.: Hydraulic properties of characteristic horizons depending on relief position and structure in a hummocky glacial soil landscape, Soil Tillage Res., 125, 123-131, 2012.

Saby, N. P. A., Bellamy, P. H., Morvan, X., Arrouays, D., Jones, R. J. A., Verheijen, F. G. A., Kibblewhite, M. G., Verdoodt, A., Üveges, J. B., Freudenschuß, A., and Simota, C.: Will European soil-monitoring networks be able to detect changes in topsoil organic carbon content?, Glob. Change Biol., 14, 2432-2442, 2008.

Sainju, U. M., Singh, B. P., and Whitehead, W. F.: Long-term effects of tillage, cover crops, and nitrogen fertilization on organic carbon and nitrogen concentrations in sandy loam soils in Georgia, USA, Soil Tillage Res., 63, 167-179, 2002.

Savage, K. E. and Davidson, E. A.: A comparison of manual and automated systems for soil $\mathrm{CO}_{2}$ flux measurements: trade-offs between spatial and temporal resolution, J. Exp. Bot., 54, 891899, 2003.

Schlichting, E., Blume, H. P., and Stahr, K.: Soils Practical, Blackwell, Berlin, 1995 (in German).

Schrumpf, M., Schulze, E. D., Kaiser, K., and Schumacher, J.: How accurately can soil organic carbon stocks and stock changes be quantified by soil inventories?, Biogeosciences, 8, 1193-1212, doi:10.5194/bg-8-1193-2011, 2011.

Six, J., Conant, R. T., Paul, E. A., and Paustian, K.: Stabilization mechanisms of soil organic matter: implications for C-saturation of soils, Plant Soil, 241, 155-176, 2002.

Skinner, R. H. and Dell, C. J.: Comparing pasture C sequestration estimates from eddy covariance and soil cores, Agric. Ecosyst. Eviron., 199, 52-57, 2015.

Smith, P., Lanigan, G., Kutsch, W. L., Buchmann, N., Eugster, W., Aubinet, M., Ceschia, E., Béziat, P., Yeluripati, J. B., Osborne, B., Moors, E. J., Brut, A., Wattenbach, M., Saunders, M., and
Jones, M.: Measurements necessary for assessing the net ecosystem carbon budget of croplands, Agric. Ecosyst. Eviron., 139, 302-315, 2010.

Sommer, M., Augustin, J., and Kleber, M.: Feedbacks of soil erosion on SOC patterns and carbon dynamics in agricultural landscapes - the CarboZALF experiment, Soil Tillage Res., 156, 182-184, 2016.

Stewart, C. E., Paustian, K., Conant, R. T., Plante, A. F., and Six, J.: Soil carbon saturation: concept, evidence and evaluation, Biogeochemistry, 86, 19-31, 2007.

Stockmann, U., Padarian, J., McBratney, A., Minasny, B., de Brogniez, D., Montanarella, L., Hong, Y., S., Rawlins, B. G., and Filed, D. J.: Global soil organic carbon assessment, Glob. Food Secur., 6, 9-16, 2015.

Van Oost, K., Quine, T. A., Govers, G., De Gryze, S., Six, J., Harden, J. W., Ritchie, J. C., McCarty, G. W., Heckrath, G., Kosmas, C., Giraldez, J. V., da Silva, J. R., and Merckx, R.: The impact of agricultural soil erosion on the global carbon cycle, Science, 318, 626-629, 2007.

Van Wesemael, B., Paustian, K., Andrén, O., Cerri, C. E. P., Dodd, M., Etchevers, J., Goidts, E., Grace, P., Kätterer, T., McConkey, B. G., Ogle, S., Pan, G., and Siebner, C.: How can soil monitoring networks be used to improve predictions of organic carbon pool dynamics and $\mathrm{CO}_{2}$ fluxes in agricultural soils?, Plant Soil, 338, 247-259, 2011.

VandenBygaart, A. J.: Monitoring soil organic carbon stock changes in agricultural landscapes: issues and a proposed approach, Can. J. Soil Sci., 86, 451-463, 2006.

VandenBygaart, A. J., Gregorich, E. G., and Helgason, B. L.: Cropland $\mathrm{C}$ erosion and burial: is buried soil organic matter biodegradable?, Geoderma, 239-240, 240-249, 2015.

Verma, S. B., Dobermann, A., Cassman, K. G., Walters, D. T., Knops, J. M., Arkebauer, T. J., Suyker, A. E., Burba, G. G., Amos, B., Yang, H., Ginting, D., Hubbard, K. G., Gitelson, A. A., and Walter-Shea, E. A.: Annual carbon dioxide exchange in irrigated and rainfed maize-based agroecosystems, Agric. For. Meteorol., 131, 77-96, 2005.

Wagle, P., Kakani, V. G., and Huhnke, R. L.: Net ecosystem carbon dioxide exchange of dedicated bioenergy feedstocks: switchgrass and high biomass sorghum, Agric. For. Meteorol., 207, 107-116, 2015.

Wang, K., Liu, C., Zheng, X., Pihlatie, M., Li, B., Haapanala, S., Vesala, T., Liu, H., Wang, Y., Liu, G., and Hu, F.: Comparison between eddy covariance and automatic chamber techniques for measuring net ecosystem exchange of carbon dioxide in cotton and wheat fields, Biogeosciences, 10, 6865-6877, doi:10.5194/bg-10-6865-2013, 2013.

Wehrhan, M., Rauneker, P., and Sommer, M.: UAV-based estimation of carbon exports from heterogeneous soil landscapes - a case study from the CarboZALF experimental area, Sensors (Basel), 16, 255, 2016.

Wuest, S.: Seasonal variation in soil organic carbon, Soil Sci. Soc. Am. J., 78, 1442-1447, 2014.

Xiong, X., Grunwald, S., Corstanje, R., Yu, C., and Bliznyuk, N.: Scale-dependent variability of soil organic carbon coupled to land use and land cover, Soil Tillage Res., 160, 101-109, 2016.

Yin, X., Goudriaan, J., Lantinga, E. A., Vos, J., and Spiertz, H. J.: A flexible sigmoid function of determinate growth, Ann. Bot., 91, 361-371, 2003. 
Yoo, K., Amundson, R., Heimsath, A. M., and Dietrich, W. E.: Erosion of upland hillslope soil organic carbon: coupling field measurements with a sediment transport model, Global Biogeochem. Cy., 19, 1-17, 2005.
Zan, C. S., Fyles, J. W., Girouard, P., and Samson, R. A.: Carbon sequestration in perennial bioenergy, annual corn and uncultivated systems in southern Quebec, Agric. Ecosyst. Environ., 86, 135$144,2001$.

Zeide, B.: Analysis of growth equations, For. Sci., 39, 594-616, 1993. 